закономерности и движущие силы процессов, которые привели к восстановлению государственной независимости украинского народа.

Ключевые слова: Украина, перестройка, демократизация, гласность, многопартийность, суверенитет, возрождение, независимость.

\author{
ABSTRACT \\ Olexandr Kryvoruchko \\ Vinnytsia Mykhailo Kotsiubynskyi State Pedagogical University, \\ PhD (History), Associate Professor (Ukraine)
}

\title{
Danylenko V.M. Ukraine in 1985-1991: the last chapter of Soviet history. \\ - K.: Institute of History of Ukraine, National Academy of Sciences of Ukraine, 2018. - 278 p.
}

The article is devoted to a monograph devoted to the changes in the socio-economic, sociopolitical, cultural and spiritual spheres of the social life of Soviet Ukraine during the period of the Gorbachev perestroika, analyzes the stages of the crisis of the party-Soviet system, describes the basic laws and driving forces of the processes that led to restoration of state independence of the Ukrainian people. The main subjects of the study are the socio-economic preconditions for the proclamation of independence, the growth of the political activity of Ukrainian society, the nationalcultural uplift, the restoration of Ukrainian statehood and the first steps of Ukraine in the path of independence.

The author successfully combines the events of the historical past and the present, which enables to fully observe the complicated process of socio-political transformations - preconditions, stages of formation and prospects of development of Ukrainian statehood. Monograph Danilenko V.M. is a significant scientific research in the study of modern history of Ukraine, an example of a tolerant attitude to the historical past and its objective comprehension, and it can be recommended to specialists, political and public figures, applicants for higher education, all who are interested in the national history of the modern period.

Key words: Ukraine, reorganization, democratization, publicity, multiparty, sovereignty, revival, independence.

Статтю надіслано до редколегії 02.05.2019 р. Статтю рекомендовано до друку 14.06.2019 р.

УДК 94 ( 477 ) ( 049.32 )

DOI: https://doi.org/10.31652/2411-2143-2019-29-121-124

\author{
Іеор Мазило \\ Вінницький національний аграрний університет \\ кандидат історичних наук, доцент (Україна)
}

\section{Україна на розломі цивілізацій / Автор-упорядник О. Домбровський. - Вінниця, 2018. - 174 с.}

\begin{abstract}
Анотація: У статті прорецензовано наукове видання «Україна на розломі цивілізацій» науковця , політика Олександра Домбровського. Автор - людина авторитетна, добре володіє матеріалом і знає предмет свого дослідження. Відтак, його твердженням і висновкам можливо довіряти. Текст книги складається з вибраних статей спрямованих на власну інтерпретацію етапних сторінок українського минулого і сьогодення, запропоновано нове бачення окремих подій історії України і як на них впливав релігійний фрактор. Сформульоване власне бачення нинішнього геополітичного вибору України. Можливо стверджувати, що автор долучився до вирішення складного завдання, яким переймаються інтелектуали і частина політикуму, - вироблення певних принципів побудови нової моделі розвитку нашого суспільства.
\end{abstract}

Ключові слова: Україна, Церква , цивілізація, історія, християнство , православ'я, глобальний світ.

Україна як в милому, так і на початку третього тисячоліття постала перед цивілізаційним вибором. Відповідь на це питання шукають політики і експерти. Власний варіант напрямку розвитку новітньої держави Україна, через аналіз культурних, історичних і внутрішньополітичних процесів запропонував науковій громадськості автор вищезгаданого видання. 
Перший розділ книги має доволі оригінальну назву - «Україна на розломі цивілізацій», зміст якого висвітлює окремі сторінки національної історії не лінійно, а через пошук відповідей на запитання: хто ми і чому ми такі ?

Можливо, це данина сьогоднішньому часу, коли Україна виборола свою помісну церкву (до речі в контексті цих подій Архієпископ Кіпру Хрисостомос II заявив, що кожна держава має право на автокефралію), вона $€$ інститутом фундаментальним, тому автор справедливо наголошує, що для нинішньої державності важливим цивілізаційним фундаментом $€$ християнство у всіх його проявах, що протягом двох тисячоліть слугує підгрунтям сучасного західного світу й нашого життя. Погоджуючись з автором, варто зауважити, що для більшості українців саме християнство східного обряду було і є духовним, культурним стрижнем, адже православ'я в кордонах України існує давно, впливає на формування духовної і матеріальної культури нашого народу, школу і виховання, побут і сім'ю. Віра в Христа Спасителя посилює молитву, спонукає до благих справ і захисту Вітчизни.

Навіть такий суспільний феномен як інтелігенція закорінений частково в православ'я, житті св'ятих, схимників і великомучеників.

Оригінальною є теза автора, що народ України, особливо в середньовіччі, перебував під тиском " бермудського трикутника » (авторська редакція) між трьома потужними державними утвореннями - Російською і Османською імперіями та Великою Польщею, що спричинило до розломів: «горизонтального» (зіткнення між християнством та ісламом) і «вертикального» (зіткнення між східним і західним християнством). Перший призвів до перетворення частини території в Дике поле, стан якого стисло передано словами Генріха Сенкевича: «Останні ознаки осілого життя на південь по Дніпру обривалися невдовзі за Чигирином, а по Дністру - відразу за Уманню; далі - до самих лиманів і до моря - лише степ, ніби двома річками облямований .

А в самому Полі ніхто не жив, хіба що по берегах, ніби островки серед моря, деінде траплялися. Скільки в тих краях битв відгриміло, скільки народу полягло - ані злічити, ані згадати .

На людей у травах полювали, немов на вовків чи на сагайдаків. Полював хто хотів. Злодій у дикому степу ховався від закону, озброєний пастух стеріг стада. Лицар шукав пригод, лихий чоловік - здобич. Козак - татарина, татарин - козака» .

За лінійною логікою перебігу історичного процесу це вже давно в минулому, як в минулому історія вищезгаданих імперій. Але автор сміливо заявляє, що розлом «вертикальний» нікуди не зник, лише пом'якшав і, що політичний вплив Росії, Європи чи Туреччини на нашу державу продовжується. Вони втягують Україну до сфери свого цивілізаційного поля, продовжуючи ії розривати .

Також автор наголошує, що російський фрактор впливу обумовлений не тільки сторіччями спільного історичного минулого, а й генотипом сильної російської держави, виплеканий на полях історичних битв, який сотнями років передавався десяткам поколінь. Він зберігся в російському менталітеті донині. Його не зламав навіть радянський період, який додав свої особливості.

Також духовними підвалинами Росії була i $є$ православна церква як її фундамент. I духовний відрив України від Росії, а саме українського православ'я від російського катастрофрічно послабить силу і міць не тільки Росії, а й вплив православної цивілізаційної культури в світі. Правда, окремі російські автори дещо декларативно стверджують, що Росія i Україна розташовані у стратегічному центрі Європи, на важливому геополітичному стику і його злам загрожує тектонічними розломами усього європейського материка.

Автор книги стверджує, що не лише правлячий український політикум зорієнтований на Європу, остання також має інтереси в Україні і він $є$ прагматично - егоїстичним. Як і Росія, Європа стає все більше зацікавленою в трудових ресурсах і багато чому ще в Україні .

Не новою, але відверто висловленою, в контексті дослідження $€$ думка автора про розрізненість українських еліт, що сильно послаблює позиції України як в минулому, так і на сучасній міжнародній арені. Книга гарно ілюстрована численними додатками, де відображено динаміку територіальних змін в Україні від часів Б. Хмельницького і до втрати Криму та частин території Донецької і Луганської областей.

Автор в коментарях до додатків демонструє знання окремих сторінок історії українських регіонів. Так, в поясненні до зображення адміністративної карти України 1944-1945рр., відзначив, що після звільнення Закарпаття Червоною армією в жовтні 1944 р. на цій території проголосили самостійну державу - Закарпатську Україну зі своїм урядом - Народною Радою. Це державне утворення проіснувало до липня 1945 р., коли відбулося возз'єднання з УРСР. Додамо, що останній крок став можливий як внаслідок визволення, так і у відповідності з волею населення краю висловлену на зібранні 663 делегатів з'їзду Народних комітетів 26 листопада 1944 р., і проголосованого ними Маніфесту про акт возз'єднання з Радянською Україною, і договору між урядами Радянського Союзу і Чехословаччини від 29 червня 1945 р. На території 
Закарпаття деякий час перебували і уповноважені чехословацького уряду , і дислоковані військові частини 18-ої радянської армії, і органи НКВС.

Певний інтерес викликає порівняльний додаток № 2 про взаємини між Україною, Росією, Польщею і Туреччиною у 1410-2016 рр. Констатується, що у 1955 р. СРСР і Польща утворили організацію Варшавського договору, який закріпив біполярну модель світу на 35 років. Також стверджується у 1991 р. фракт визнання незалежності України Польщею, Росією та Туреччиною. А через два десятки років перемога Революції Гідності стає поштовхом до анексії Криму Росією . Остання, не обмежуючись загарбанням півострова, розпочинає вторгнення на Донбасі, підтримує сепаратизм і незаконні військові формування на Сході України .

Автор у післямові наголосив, що ця книга не $є$ фундаментальним науковим дослідженням щодо минулого і проблем сучасної України, а лише першою спробою такого аналізу. Вважаємо, що запропонований автором дослідження підхід і пояснення окремих складних сторінок історії й нагальних проблем сучасної України зацікавить науковців і широкий читацький загал.

\title{
Игорь Мазыло \\ Винницкий национальный аграрный университет, кандидат наук , доцент ( Украина )
}

\section{Украина на разломе цивилизаций. / Автор-составитель А. Домбровский. - Винница, 2018. - 174 с.}

\begin{abstract}
Аннотация: B статье прорецензировано научное издание «Украина на разломе цивилизаций " ученного и политика Александра Домбровского. Автор - личность авторитетная, достаточно глубоко владеет материалом и хорошо знаком с предметом своего исследования. Значит его утверждениям и выводам возможно доверять. Текст книги составлен из избранных статей направленных на авторскую интерпретацию этапных странии украинского прошлого и настоящего времени. В книге сформулирован новый подход к анализу отдельных странии истории Украины и роли религиозного фрактора в событиях прошлого и настоящего. Представлено собственное видение геополитического выбора Украины.
\end{abstract}

Ключевые слова: Украина, Церковь, цывилизация, история, християнство, православие, глобальный выбор.

\author{
ABSTRACT \\ Ihor Mazylo \\ Vinnytsia National Agrarian University \\ PhD (History), Associate Professor (Ukraine)
}

\section{Ukraine on the Breakdown of Civilizations. / Author of the compiler O.Dombrovskyi. - Vinnytsia. 2018. - 174 p.}

The scientific publication "Ukraine on the Breakdown of Civilizations" by scientist and politician Oleksandr Dombrovskyi is patended in this article. The author is a very authoritative person who perfectly knows the material and the subject of his research. His statements and conclusions can be trusted. The text of the book consists of selected articles, the content of which is directed to comprehend certain historical stages of the Ukrainian past and present. He applied a new approach to the analysis of certain events due to the influence of the religious factor. The latter is very relevant. The Church in modern Ukraine is becoming more popular the spiritual life of society. Parish grows, churches are built, monasteries are opened. .The long-standing struggle for autocephaly has been successfully completed.

The study rightly states that the religious factor caused a split in Ukrainian society during the Middle Ages. The confirmation is the conclusions of scientists and the words of the Great Kobzar that the Union of Cossacks with the poles were put up and if not Jesuits, they might not have been cut. The author claims that Ukrainians inherited a complex history. Each region has its own cultural, linguistic, ethnic and religious peculiarities. The researcher emphasizes that the Church of Christ is capable of uniting people through faith in one God on the principles of trust, love and mutual respect. In this way, the Christian church reminds citizens of their spiritual unity.

It can be affirmed that the author has partly joined the solution of the difficult task that the intellectuals and the thinking part of the Ukrainian politics are working on - the elaboration of certain principles for the development of a new model of social development. He states that Ukraine has a unique national potential: its own extraordinary and rich culture and spiritual tradition, faith. The grace 
of holy baptism spread to many peoples in the Kiev land. There is a good reason that Kiev City was called the Second Jerusalem. Having a glorious past, a thousand-year church tradition, a statebuilding potential, Ukrainians are rightly striving for a better future

Key words : Ukraine, church, civilization, history ,Christianity, orthodox . world world

Статтю надіслано до редколегії 03.05.2019 р.

Статтю рекомендовано до друку 12.06.2019 р. 